\title{
Protein levels for Chios lambs given high concentrate diets
}

\author{
M. HADJIPANAYIOTOU \\ Agricultural Research Institute, Nicosia, Cyprus
}

\begin{abstract}
Summary
Two trials were conducted to study the effects of three dietary crude protein (CP) levels $(178,158$ and $137 \mathrm{~g} / \mathrm{kg}$ dry matter) on growth characteristics of Chios lambs and the digestibility of the diets.

Male lambs grew faster, consumed more feed and utilized feed more efficiently than female lambs. The final weight and weight gain of male lambs on the high $\mathrm{CP}$ diet were higher than those on the low CP diet. Serum urea nitrogen was correlated $(r=0.55)$ with dietary protein level in the males, but not in the females. Neither diet nor sex had a significant effect on rumen $\mathrm{NH}_{3}-\mathrm{N}$ concentration or $\mathrm{pH}$. Rumen microbial protein was highest $(P<0.01)$ on the high $C P$ diet. $C P$ level had no effect on any of the carcass measurements. There were no significant differences among diets in the apparent digestibility of dry matter, organic matter or $\mathrm{CP}$. Urinary nitrogen output increased in response to increments of dietary $\mathrm{CP}$ concentration. These present data show that the $\mathrm{CP}$ requirements of female Chios lambs are considerably lower than those of males. Maximum growth of male Chios lambs during this stage of fattening can be obtained with 16 p. 100 (dry matter) dietary $\mathrm{CP}$ concentration.
\end{abstract}

\section{Introduction}

Dual purpose (meat and milk) sheep are found in relatively few places out of the Middle East region, and data on their performance are limited. Lambs are generally weaned early from their dams (HADJIPANAYIOTOU \& LouCA, 1976) and are fed on high grain, protein supplemented diets to reach a high slaughter weight or sexual maturity at an early age.

Diets of high crude protein (CP) concentration may be effective in promoting live weight gains, but because of the partial degradation of dietary protein in the rumen, such protein is likely to be less efficiently utilized (Roy et al., 1977). In a previous experiment with younger growing Chios lambs (Anonymous, 1974), it was observed that at CP levels above 17.5 p. 100 (dry matter basis), there was no response in terms of live weight gain and/or feed conversion efficiency. In view of the increased cost of protein supplements, information concerning the effects of lower levels of dietary protein on performance of older lambs and estimation of requirements for optimal growth is evident. 
The present paper describes two trials designed to study the effects of protein concentration on live weight changes, feed efficiency, digestibility of the diets, carcass composition and rumen metabolites of Chios lambs.

\section{Material and methods}

Two trials were conducted to study the effects of dietary protein concentration on the growth rate of Chios lambs and the digestibility of the diets. The completely random design was used in both trials.

\section{Growth trial}

Sixty Chios lambs, 30 males and 30 females were used. Lambs were weaned from their dams at 42 days of age. From the age of 2 weeks they had free access to a concentrate mixture (180 g CP/ $\mathrm{kg}$ dry matter) and lucerne hay. Following weaning all lambs were offered the same concentrate mixture ad libitum plus $0.1 \mathrm{~kg}$ lucerne hay (182 $\mathrm{g} \mathrm{CP} / \mathrm{kg}$ dry matter) daily. The animals were allocated on the three diets at the age of approximately 3 months. The diets consisting of concentrates (mash, fed ad libitum $)$ and lucerne hay $(0.1 \mathrm{~kg} / \mathrm{head}$ daily) were offered in separate feed containers. The three diets were composed of lucerne hay $(7.6$ p. 100) and one of each of the concentrates 1,2 or 3 (tabl. 1) for diets A, B and C, respectively.

\section{TABle 1}

Composition and analyses of the concentrate mixture (Dry matter basis). Composition et analyses chimiques des mélanges concentrés.

\begin{tabular}{|c|c|c|c|}
\hline & \multicolumn{3}{|c|}{ Mixture * } \\
\hline & 1 & 2 & 3 \\
\hline $\begin{array}{l}\text { Estimated concentration of crude protein } \\
\quad(\mathrm{g} / \mathrm{kg} \mathrm{DM}) \ldots \ldots \ldots \ldots \ldots\end{array}$ & 180 & 160 & 140 \\
\hline \multicolumn{4}{|l|}{ Ingredient $(\mathrm{kg} / \mathrm{ton})$} \\
\hline Rolled barley & 815 & 868 & 920 \\
\hline Soyabean meal & 135 & 82 & 30 \\
\hline Wheat bran .. & 40 & 40 & 40 \\
\hline Limestone . & 8 & 8 & 8 \\
\hline Salt .... & 2 & 2 & 2 \\
\hline \multicolumn{4}{|l|}{ Chemical analysis $(\mathrm{g} / \mathrm{kg})$} \\
\hline Crude protein $\ldots$ & 178.3 & 156.3 & 133.5 \\
\hline Ether extract & 19.7 & 20.1 & 21.3 \\
\hline Crude fibre & 51.7 & 53.2 & 57.4 \\
\hline Ash $\ldots \ldots \ldots$ & 50.7 & 48.5 & 52.3 \\
\hline
\end{tabular}

* Two $\mathrm{kg}$ of a vitamin-trace element mixture (Vita 6, Vita-trace nutrition, Cyprus) were added per ton of concentrate mixture. 
The CP concentration of the three finished diets (concentrate + hay) was 178 (A), 158 (B) and 137 (C) $\mathrm{g} / \mathrm{kg}$ dry matter. The lambs were housed in six adjacent pens. Sexes were kept apart. Group feed residues were collected and weighed at least once a week. Feed samples were collected routinely for dry matter (DM) and chemical analyses (Hadjipanayiotou, 1982). All lambs were weighed at the beginning, at the end of the trial and weekly during the course of the 6-week trial. The animals had free access to water.

Rumen liquor samples were collected $(10.00 \mathrm{~h})$ from 15 male and 15 female lambs $(10 /$ diet $)$ at the end of the trial for the determination of $\mathrm{pH}$ and $\mathrm{NH}_{3}-\mathrm{N}$ concentration. Collection, processing and analysis of samples were made as outlined by Haditpanayiotou (1982). Blood samples were also collected (10.00 h) from 42 lambs (i.e. 14/diet) in a centrifuge tube, via jugular puncture. Blood serum was separated by the method of ARCHER (1965) and analysed for urea concentration colorimetrically (Urea Kit-Bio Merieux, Charbonnières-les-Bains, France).

Four male lambs per group selected for similar liveweight were slaughtered for carcass evaluation. The weight of hot and cold carcass, digestive tract, mesenteric and kidney fat, and tail were recorded. Following $24 \mathrm{~h}$ storage in a cooler each carcass was bisected by sawing down the centre of the vertebral column. The «best end neck» (7th to 10th rib inclusive) of the left side was dissected into lean, fat, tendons and bones. Joints were weighed to the nearest gram. Immediately after slaughter, rumen contents were emptied in a container and after being thoroughly mixed, subsamples were used for dry matter determination and to measure the microbial protein in rumen fluid, using tungstic acid as protein precipitating agent and the differential centrifugation technique (SHUltz \& SHulTZ, 1970).

\section{Digestion trial}

Twelve male lambs (4/diet) approximately $39 \mathrm{~kg}$ live weight were used at the end of fattening, to determine apparent digestibility coefficients of the three diets. The animals were housed for 17 days in metabolic crates, designed for the separate collection of urine and faeces. The first 10 days served as adaptation period.

The animals were offered concentrates and lucerne hay (daily intake $87 \mathrm{~g}$ ) in separate feed containers. Daily total dry matter intake was $0.917,0.836$ and $0.872 \mathrm{~kg}$ per day for diets $\mathrm{A}, \mathrm{B}$ and $\mathrm{C}$, respectively. Collection processing and analyses of feed, faeces and urine samples were made as outlined by HADIIPANAYIOTOU (1982).

\section{Statistical analysis}

Lamb growth data were analysed by least squares procedures (HARVEY, 1975), serum urea nitrogen, rumen $\mathrm{NH}_{3}-\mathrm{N}$ and $\mathrm{pH}$ by two-way analysis of variance (STEEL \& TORRIE, 1960) and digestibility coefficients, nitrogen balance, carcass traits and rumen microbial protein data by one way analysis of variance (STEEL \& ToRRIE, 1960). Data on carcass composition were analysed using cold carcass weight as covariate. Differences among treatment means were tested using the Duncan's new multiple range test. 


\section{Results}

The effects of dietary protein concentration and sex of lambs on final weight, weight gain, dry matter intake, feed conversion ratio, serum urea, rumen $\mathrm{NH}_{3}-\mathrm{N}$ concentration and $\mathrm{pH}$ are summarized in table 2 . Male lambs grew faster $(\mathrm{P}<0.001)$, consumed more feed and utilized feed more efficiently than female lambs. The daily intake of male lambs over the entire feeding period was 15 p. 100 higher than that of female lambs. Protein level did not affect feed intake. Initial weight on test had no significant effect on weight gain, but significantly $(\mathrm{P}<0.001)$ affected final weight. Dietary protein concentration significantly affected the final weight and weight gain of male lambs only. Differences among diets were significant between diets $\mathrm{A}$ and $\mathrm{C}$ but not between $\mathrm{A}$ and $\mathrm{B}$ or $\mathrm{B}$ and C. Figure 1 shows the effect of $\mathrm{CP}$ concentration on liveweight gain at weekly intervals. Overall, there was a trend towards higher rate of growth of lambs given the high CP diets (A and B) during the early stages of fattening. Over the last two weeks of fattening the weight gain of lambs (males and females) given the lowest CP diet (14 p. 100) was similar to that of lambs given the highest $(18$ p. 100) CP diet. Serum urea concentration was significantly affected by diet $(P<0.01)$ and $\operatorname{sex}(\mathrm{P}<0.001)$. Serum urea concentration was positively correlated with level of dietary protein in the males, but not in the females. Neither diet nor sex had a significant effect on rumen $\mathrm{NH}_{3}-\mathrm{N}$ concentration and $\mathrm{pH}$. The correlation between rumen $\mathrm{NH}_{3}-\mathrm{N}$ and serum urea was positive and high $(\mathrm{r}=0.55)$.

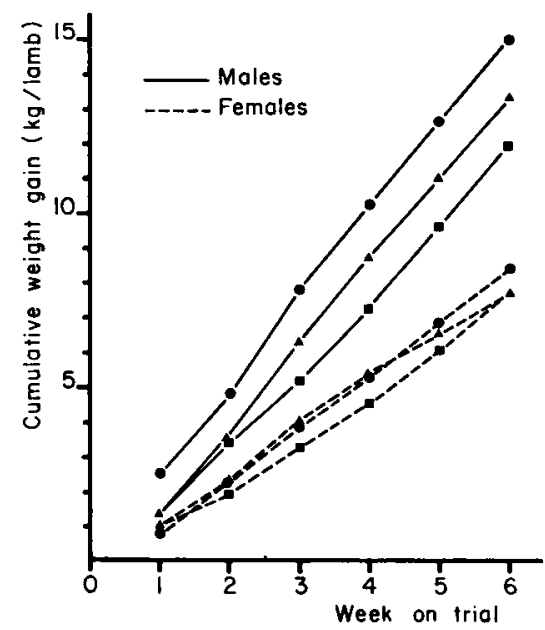

FIG. 1

Cumulative weight gain of Chios lambs given three diets with 178 (•), 158 (ه) and 137 (०) $\mathrm{g} \mathrm{CP} / \mathrm{kg}$ dry matter.

Gains de poids cumulés d'agneaux Chios recevant trois régimes avec $178 \mathrm{~g}(\bullet), 158 \mathrm{~g}(\mathrm{~A})$ et $137 \mathrm{~g}(\bullet) \mathrm{MAT} / \mathrm{kg}$ matière sèche. 
PROTEIN LEVELS FOR CHIOS LAMBS

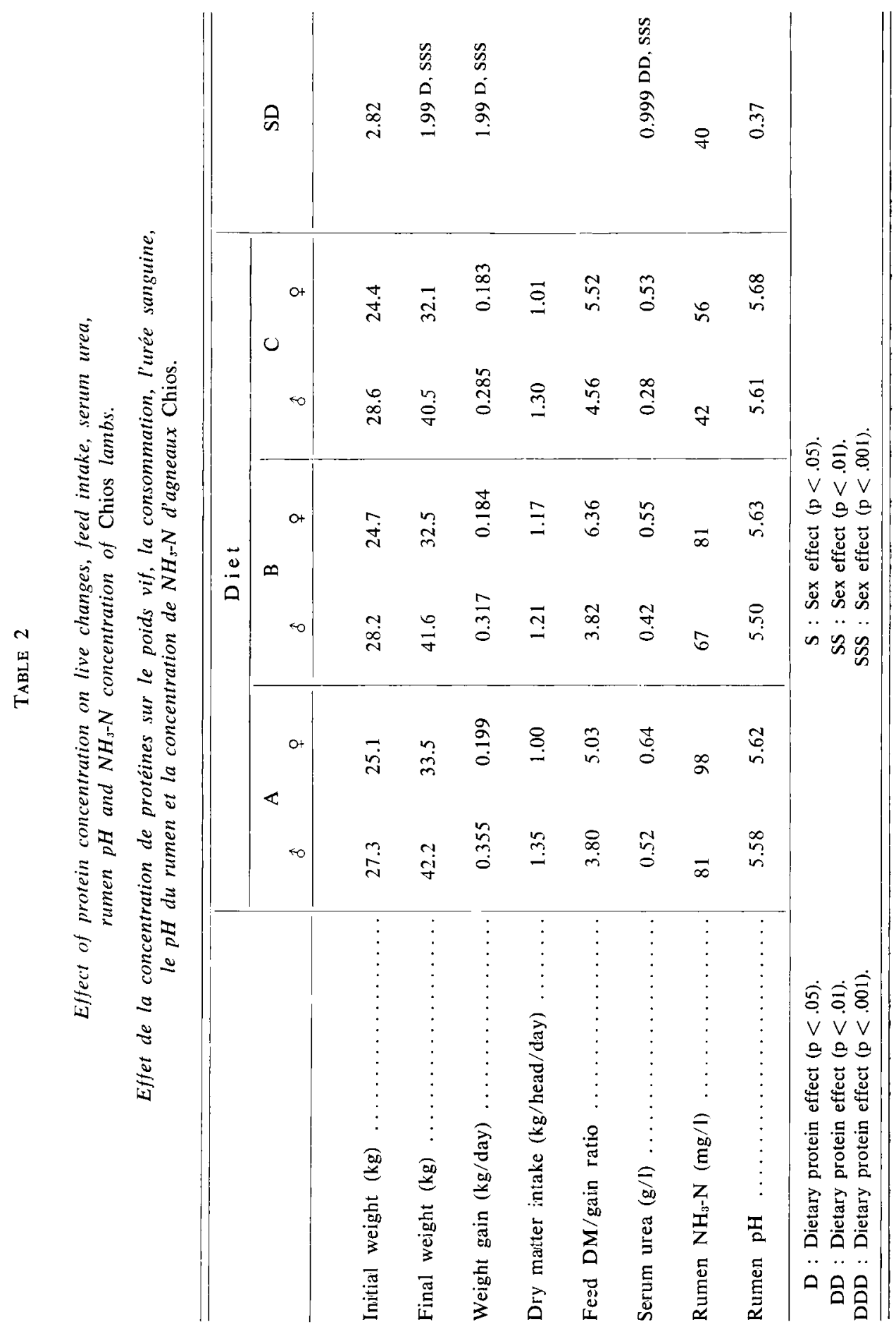


Table 3 gives data on the effects of dietary protein concentration on various indices of carcass composition and rumen microbial protein. Slaughter weight was higher than final weight (tabl. 2 and 3 ) in all three diets, because these animals were slaughtered five days after the end of the trial. Protein level did not affect the composition of the "best end neck» joint or other carcass measurements. Rumen microbial protein was significantly higher in diet A compared to diets B and C.

TABLE 3

Slaughter, dissection and rumen microbial protein data of lambs ${ }^{*}$.

Résultats d'abattage : caractéristiques des agneaux, composition et protéines microbiennes du rumen.

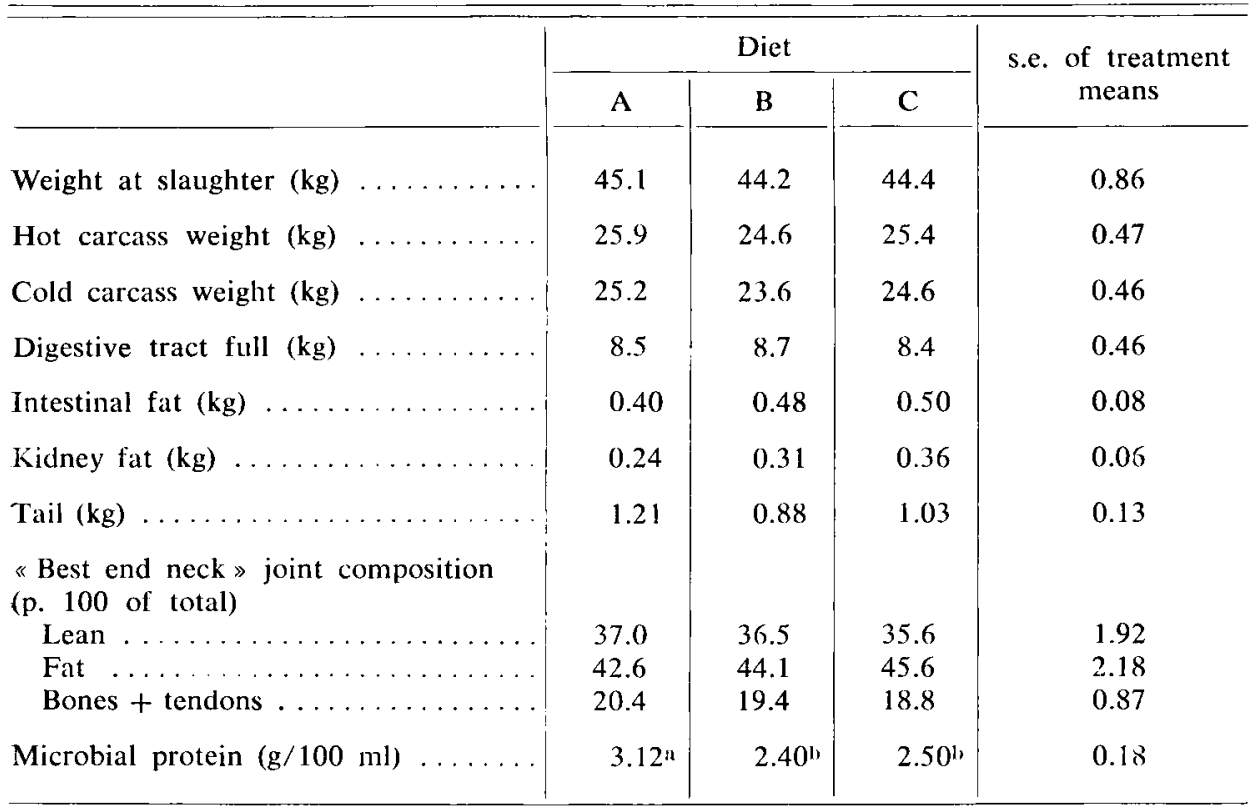

* Mean on the same line with unlike superscripts differ $(\mathrm{p}<.05)$.

Apparent digestibility values and nitrogen balance results for the three diets are presented in table 4. There were no significant differences among diets in the apparent digestibility of DM, organic matter (OM) or CP. Urinary nitrogen output increased in response to increments of dietary CP concentration. Loss of dietary nitrogen occurred primarily via the urine. Faecal nitrogen losses were 32, 33 and 37 p. 100 of the total nitrogen loss for diets A, B and C, respectively. Nitrogen retained, as a percentage of nitrogen intake, and nitrogen absorbed although higher in diets $\mathrm{B}$ and $\mathrm{C}$ compared to diet $\mathrm{A}$ were not significantly different from each other. 
TABLE 4

Effects of protein concentration on apparent digestibility coefficients and nitrogen balance*.

Effets de la concentration en protéines sur le coefficient d'utilisation digestive et le bilan azoté.

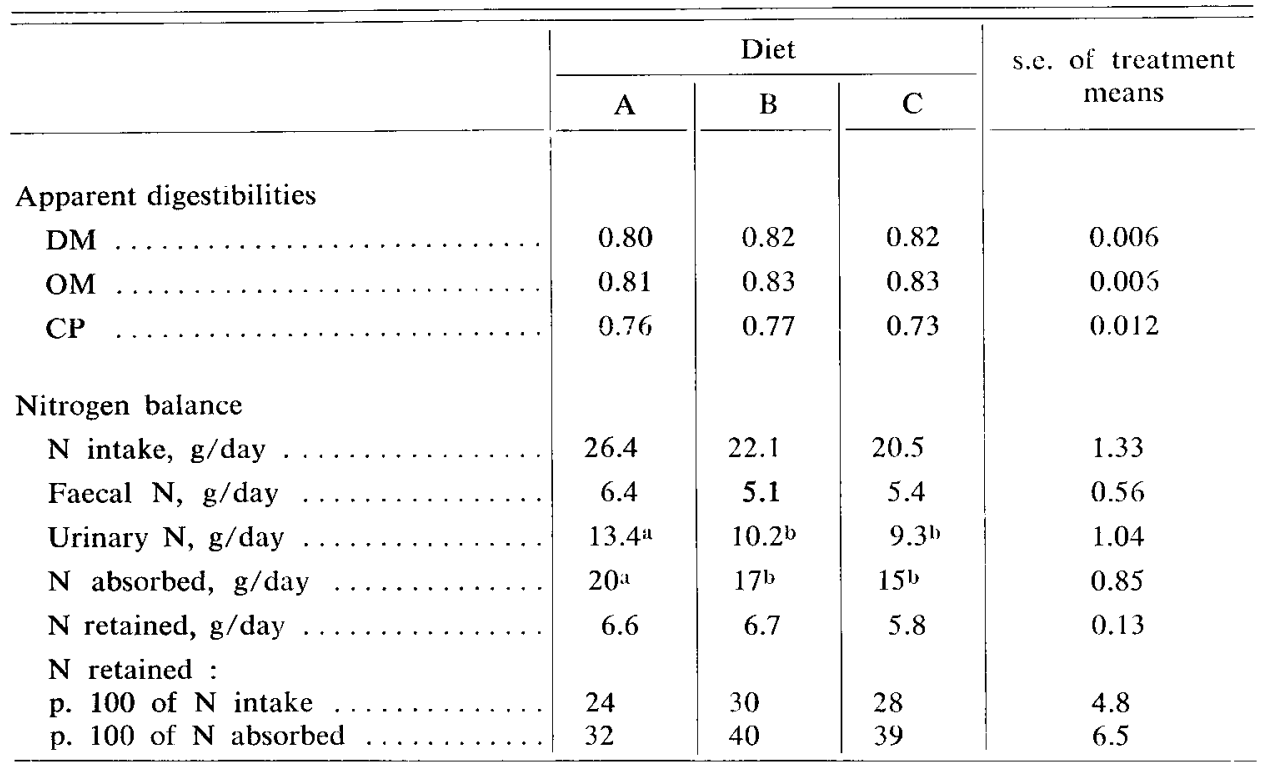

* Means on the same line with unlike superscripts differ $(p<.05)$.

\section{Discussion}

The performance of Chios male lambs improved by increasing the CP content of diets from 14 to 18 p. 100, dry matter basis, but that of females remained unchanged. The present findings suggest that the protein requirements of female lambs are considerably lower than those of males.

The effects of sex on body weight observed in this study are consistent with previous reports (ANDREWS \& ORSKOV ,1970 a HADJipanayiotou \& Louca, 1976). Differences in the growth rate between sexes were consistent throughout the fattening period, contrary to the results of ANDREWS \& ORsKov (1970 b) who reported greater sex differences as mean live weight increased.

Total DM intake did not increase with protein level, indicating that all levels of protein promoted optimum dry matter intake.

There was a trend towards lower percentage lean carcass in the «best end neck " joint with decreasing dietary CP concentration. However, these data, as well as, 
those of REID et al. (1968), showed no significant effect of protein concentration on body composition. In other studies (Orskov et al., 1971), body composition at constant weight was altered by dietary protein concentration. The low value for lean to fat ratio obtained in this study $(0.82)$ can be attributed to the high slaughter weight for the breed and to the feeding regime (ad libitum feeding of concentrates). The similar slaughter weight of lambs on the three diets and the high slaughter weight might be the reasons for the insignificant effect of dietary protein on body composition. In addition, it is widely accepted that the contribution of CP in excess of requirements has no effect on growth rate and carcass composition. This was possibly the case during the last stage of fattening judged by the similar liveweight gain of lambs on the low and high CP diets (fig. 1).

The apparent digestibility for DM, OM and CP, was similar for all three diets. Other workers (VErRA et al., 1980; MEHREZ \& ORSKOV, 1978) have reported increases in dry matter digestibility with increasing protein concentration in high grain diets fed to calves and lambs. In contrast, PAPAS (1977) reported that various protein levels had no effect on dry matter digestibility. In agreement with the data of Black, Pearce \& Tribe (1973) faecal nitrogen excretion was not affected by nitrogen intake, but urinary nitrogen excretion increased with increasing dietary nitrogen concentration. Furthermore, in line with the studies of BLACK, Pearce \& TRIBE (1973) nitrogen retained was not increased when nitrogen intake was increased above $15.5 \mathrm{~g}$ per lamb daily.

Serum urea nitrogen levels reflected dietary nitrogen levels in agreement with the data of Byers \& MOXON (1980) and THOMPSON \& Riley (1980) with cattle. The positive correlation between serum urea nitrogen and rumen $\mathrm{NH}_{3}-\mathrm{N}(\mathrm{r}=0.55)$ is in accordance with the data of THOMPSON \& RILEY (1980). Changes in blood urea concentration are directly related to $\mathrm{NH}_{3}-\mathrm{N}$ production in the rumen. The concentration of proteins precipitated by the tungstic acid was higher in the rumen liquor of lambs given the highest CP diet. In case this method (Shultz \& Shultz, 1970) gives an indication of the microbial population in the rumen, the present data are in accordance with those of Hume, MOIR \& SOMERs (1970) who reported that maximum microbial protein growth occurred when rumen $\mathrm{NH}_{3}-\mathrm{N}$ concentration was $81 \mathrm{mg} / 1$.

Earlier studies with young growing (45-90 days old) Chios lambs (Anonymous, 1974) showed that live weight and feed efficiency were improved with increasing level of protein in the diet up to 17.5 p. 100 DM basis. The present data showed that protein requirements of female Chios lambs are considerably lower than those of males and possibly lower than the lowest level (14 p. $100 \mathrm{CP}$ dry matter) used in the present study. Furthermore, the present data indicate that during this stage of fattening CP concentration can be reduced to 16 p. 100 dry mater without any adverse effect on the growth rate of Chios male lambs.

Accepted for publication in March 1982.

\section{Acknowledgements}

The author is grateful to L. Hadjiparaskevas, A. Photiou, C. Heracleous, M. Theodoridou, M. Karavia and N. Parouti for skilled technical assistance. 


\section{Résumé \\ Besoins azotés des agneaux de race Chios recevant des régimes composés d'aliment concentré}

Des agneaux mâles et femelles ont été engraissés, au cours de 2 essais successifs, avec des régimes composés d'aliment concentré offert à volonté et de $100 \mathrm{~g}$ de foin de luzerne. Les teneurs en matières azotées totales (MAT) des régimes expérimentaux variaient de 178 à 158 et $137 \mathrm{~g} \mathrm{MAT} / \mathrm{kg}$ MS. Le premier essai qui portait sur 60 agneaux (30 mâles et 30 femelles) (pesant 28 et $25 \mathrm{~kg}$ respectivement en début d'essai) avait comme objectif l'étude des effets de ces 3 niveaux sur les performances et la composition corporelle des agneaux. Le second (12 agneaux mâles de $39 \mathrm{~kg}$ ) était destiné à la mesure de la digestibilité des régimes et du bilan azoté des animaux.

L'augmentation de la teneur en MAT du régime s'est traduite par une augmentation de la vitesse de croissance, chez les mâles essentiellement. Ceux-ci ont eu un niveau de consommation, une vitesse de croissance et une efficacité alimentaire supérieurs à ceux des femelles, quelle que soit la teneur en MAT du régime. La composition de leur carcasse n'a pas été modifiée.

La teneur en urée sanguine a varié avec la teneur en MAT du régime, la corrélation observée n'était cependant significative que pour les mâles. Si la teneur en azote ammoniacal du contenu du rumen et son $\mathrm{pH}$ n'ont pas été modifiés par le régime, celui-ci a eu pàr contre un effet significatif sur la quantité de protéines microbiennes du rumen.

L'augmentation de la teneur en MAT du régime n'a pas eu d'effet sur la digestibilité de la matière sèche, de la matière organique ou des matières azotées mais elle a accru de manière significative l'excrétion d'azote urinaire.

Les résultats obtenus montrent que les besoins azotés des agneaux Chios femelles sont inférieurs à ceux des mâles. Pour ces derniers, une teneur de 16 p. 100 est suffisante pour obtenir une croissance maximum pendant la phase de croissance-engraissement.

\section{References}

ANDREws R.P., Orskov E.R., 1970 a. The nutrition of the early weaned lamb. II. - The effect of dietary protein concentration, feeding level and sex on body composition at two live weights. J. Agric. Sci. Camb., 75, 19-26.

ANDREws R.P., ORskov E.R., 1970 b. The nutrition of the early weaned lamb. I. - The influence of protein concentration and feeding level on rate of gain in body weight. J. Agric. Sci. Camb., 75, 11-18.

Anonymous, 1974. Studies on the protein requirements of Chios sheep. Agric. Res. Institute, Annual Report, 71-76, Cyprus.

ArCher R.K., 1965. Haematological techniques for use on Animals, 115, Backwell Scientific publications, Oxford, U.K.

Black J.L., Pearce C.R., Tribe D.E., 1973. Protein requirements of growing lambs. Brit. J. Nutr., 30, 45-60.

Byers F.M., Moxon A.L., 1980. Protein and selenium levels for growing and finishing beef cattle. J. Anim. Sci., 50, 1136-1144.

Hadjipanayiotou M., 1982. Effects of sodium bicarbonate on milk yield and milk composition of goats and rumen fermentation of sheep. J. Dairy Sci., 65, 59-64.

Hadipanayiotou M., Louca A., 1976. The effects of partial suckling on the lactation performance of Chios sheep and Damascus goats and the growth rate of the lambs and kids. J. Agric. Sci. Camb., 87, 15-20.

HARVEY W.R., 1975. Least squares analysis of data with unequal subclass numbers. United States Department of Agriculture, ARS, H-4, Washington, DC. 
Hume I.D., Molr R.J., Somers M., 1970. Synthesis of microbial protein in the rumen. I. - Influence of the level of nitrogen intake. Austr. J. agr. Res., 21, 305-314.

Mehrez A.Z., Orskov E.R., 1978. Protein degradation and optimum urea concentration in cereal-based diets for sheep. Brit. J. Nutr., 40, 337-345.

Orskov E.R., McDonald I., Fraser C., Elizabeth L. Corse, 1971. The nutrition of the early weaned lamb. III. - The effect of ad libitum intake of diets varying in protein concentration on performance and on body composition at different live weights. J. Agric. Sci. Camb., 77, 351-361.

Papas A., 1977. Protein requirements of lactating Chios ewes. J. Anim. Sci., 44, 672-679.

Reid J.T., Bensadoun A., Bull L.S., Burton J.H., Gleesen P.A., Han L.K., Joo Y.D., Johnson D.E., McManus W.R., Paladines O.L., Stroud J.W., Tyrrel H.F., Van NiekiRK B.D.H., Wellington G.H., Wood J.D., 1968. Changes in body composition and meat characteristics accompanying growth of animals. Proc. Cornell. Nutr. Conf., 18-127.

Roy J.H.B., Balch C.C., Miller E.L., Orskov E.R., Smith R.H., 1977. Calculation of the $\mathrm{N}$-requirement for ruminants from nitrogen metabolism studies. In : 2nd International Symposium on Protein Metabolism and Nutrition, E.A.A.P. Publ. No 22, Centre for Agricultural Publishing and Documentation, Wageningen, 126-129.

Shultz T.A., Shultz Elena, 1970. Estimation of rumen microbial nitrogen by three analytical methods. J. Dairy Sci., 53, 781-784.

Steel R.G.D., Torrie J.H., 1960. Principles and Procedures of Statistics, 481, McGrawHill, New York.

Thompson W.R., RileY J.G., 1980. Protein levels with and without monensin for finishing steers. J. Anim. Sci., 50, 563-571.

Veira D.M., Macleod G.K., Burton J.H., Stone J.B., 1980. Nutrition of the weaned Holstein calf. II. - Effect of dietary protein level on nitrogen balance, digestibility and feed intake. J. Anim. Sci., 50, 945-951. 